AC 2010-327: HOW THE CIVIL ENGINEERING BOK2 CAN BE IMPLEMENTED AT THE UNIVERSITY OF LOUISIANA

Kenneth McManis, University of Louisiana 


\title{
How the Civil Engineering BOK2 Can Be Implemented at the University of Louisiana
}

\begin{abstract}
The purpose of this paper is to provide a comprehensive analysis of the University of Louisiana's civil engineering curriculum with respect to the second edition of the Civil Engineering Body of Knowledge for the $21^{\text {st }}$ Century (BOK2), or more specifically the BOK2 outcomes associated with the baccalaureate degree since the BOK2 includes outcomes for baccalaureate and postbaccalaureate formal education as well as pre-licensure experience. Specific emphasis is given those BOK2 outcomes that previous survey data identified as being a challenge for many programs to address within current curricular design. The curriculum, as developed, is considered to be BOK2-complient, in addition to meeting current university graduation and $\mathrm{ABET} / \mathrm{EAC}$ accreditation requirements.
\end{abstract}

\section{Introduction}

The first edition of the Civil Engineering Body of Knowledge for the $21^{\text {st }}$ Century ${ }^{1}$ (BOK1) was released in January 2004. Based on various inputs, a second edition of the Civil Engineering Body of Knowledge for the $21^{\text {st }}$ Century $^{2}$ (BOK2) was developed and released in February 2008. The BOK1 has already impacted accreditation criteria and civil engineering curricula. The BOK2, while being more recent and not yet addressed within accreditation criteria, is motivating additional change in some civil engineering curricula. Considering specifically the BOK2, a coordinated list of 24 outcomes is presented within three outcome categories: Foundational, Technical and Professional. The outcomes define the desired level of achievement defined according to Bloom's Taxonomy for the cognitive domain ${ }^{3,4}$. Additionally, the BOK2 has recommended outcome achievement targets for each portion of the fulfillment pathway: for the baccalaureate degree (B), post-baccalaureate formal education (M/30), and pre-licensure experience $(\mathrm{E})$. The emphasis herein is on those outcomes and achievement targets for the baccalaureate degree.

The BOK2 Outcomes Rubric, using Bloom’s Taxonomy, is graphically presented in Figure 1. The reader is cautioned that this is a simple graphical representation of the full rubric only and should refer to the full rubric as presented in Appendix I of the BOK2 report ${ }^{2}$ (which is available at www.asce.org/raisethebar). What is clearly represented in Figure 1 is the recommended level of achievement that an individual must demonstrate for each outcome to enter the future practice of civil engineering at the professional level and, for each outcome, the level of achievement (LOA) expected to be fulfilled through the baccalaureate degree (B), the master's degree or equivalent post-baccalaureate formal education (M/30), and pre-licensure experience $(\mathrm{E})$.

Recently, ASCE's Body of Knowledge (BOK) Educational Fulfillment Committee (BOKEdFC) conducted an analysis of how well civil engineering curricula, in their current design, achieve the educational outcomes of both the first and second editions of the civil engineering $\mathrm{BOK}^{5}$. The results of a curricular review by ten representative civil engineering programs were presented 
along with possible explanations as to why current curricula may fulfill or fall short of fulfilling specific outcomes. Figure 2 presents the results of one of the surveys, specifically one in which programs reported, for the BOK2 outcome rubric, at what level of achievement they believe all of the outcome statement is fulfilled by all of their baccalaureate graduates. A color coding was provided to assist with visualizing the results of the survey. Green cells indicate baccalaureate graduates of 8 to 10 programs are believed to be fulfilling the LOA, yellow cells indicate graduates of 5-7 programs are fulfilling the LOA, and red cells indicate baccalaureate graduates of 4 or less programs are fulfilling the specified LOA. To further help with visualizing the results, the first column of each table corresponding to the outcome number has been similarly color coded consistent with the LOA corresponding to the " $\mathrm{B}$ " level for each outcome. For example, Outcome 6 (Humanities) is colored red and shows that six of the ten (yellow) surveyed programs believe all of the outcome is fulfilled by all of their baccalaureate graduates at a LOA 1, five of ten (yellow) at a LOA 2, and three of ten (red) at the targeted LOA 3.

Based on the survey data and analysis, the BOKEdFC ${ }^{5}$ concluded that several BOK2 outcomes may be "challenging" for many programs to address in today's civil engineering curricula. These include the nine "red outcomes" shown in Figure 2 (i.e., Outcomes 3 - Humanities, 4 Social Sciences, 10 - Sustainability, 11 - Contemporary Issues \& History, 12 - Risk \& Uncertainty, 17 - Public Policy, 18 - Business \& Public Administration, 19 - Globalization, and 20 - Leadership). In addition, the committee identified Outcome 5 - Material Science and Outcome 24 - Professional \& Ethics as outcomes that may be challenging for programs to fully implement.

The purpose of this paper is to provide a comprehensive analysis of the University of Louisiana's civil engineering curriculum with respect the BOK2 outcomes associated with the baccalaureate degree. Specific emphasis is given herein to these identified "challenging" outcomes.

\section{Institutional Profile}

The University of Louisiana at Lafayette is a public institution of higher education offering the bachelor, master, and doctoral degrees. It is the largest member of the University of Louisiana System with an enrollment of approximately 16,000 students. Within the Carnegie classification, [University A] is designated as a Research University with high research activity. Through instruction, research, and service, the University promotes regional economic and cultural development, explores solutions to national and world issues, and supports scholars who contribute in the advancement of knowledge, cultivate aesthetic sensibility, and improve the material conditions of humankind.

During the 1990's, the State's Board of Regents was concerned that the length of time required to complete a baccalaureate degree was growing beyond the stated four years. Therefore, it was stipulated that the program length for the baccalaureate degree be 128 semester hours, and any program requiring more than 128 must be properly justified. Baccalaureate degree programs at [University A], in general, are 128 semester credit hours or less, which include a minimum of 42 semester hours of core courses or general degree requirements in order to graduate. 
The Department of Civil Engineering resides within the University of Louisiana's College of Engineering, which includes five engineering departments and a department of industrial technology. The College of Engineering offers undergraduate and graduate engineering programs in Chemical Engineering, Civil Engineering, Electrical Engineering, Mechanical Engineering, and Petroleum Engineering. A bachelor of science in civil engineering and a master of science in engineering with a civil engineering option is offered through the Civil Engineering Department. Currently there are approximately 150 undergraduate students pursuing a B.S. degree in civil engineering. There are approximately 20 graduate students; mostly full-time students supported through research or teaching assistantships. The department faculty includes 9 tenure track positions, one instructor, and severable adjunct-faculty practitioners, as needed.

\section{Current BS in Civil Engineering Curriculum}

The academic mission of the undergraduate program envisions graduates that will be competitive and employable by engineering firms, government agencies, and a curriculum that will provide an educational foundation for those who pursue advanced degrees. Professional licensure is promoted, and students are strongly encouraged to take the NCEES Fundamentals in Engineering Exam.

Curriculum: The required program of courses provides breadth and depth in five (5) civil engineering sub-discipline areas; namely, structural, environmental, water resources, geotechnical, and transportation engineering, Table 1 . The program ensures breadth with the coverage of five (5) major areas of civil engineering and depth with the requirement for advanced topics in those five subject areas. The ABET accreditation review for the civil engineering program was conducted in the fall of 2007. The next evaluation will take place in 2013.

Core curriculum: The University’s “core curriculum” of 42 semester hours are general degree requirements that satisfy both the State's Board of Regents and the University. These core courses include minimum requirements for courses in English communication (6- hours), mathematics (6-hours and, with permission of the Dean, three hours may be statistics), the behavioral sciences (6-hours - anthropology, economics, geography, political science, psychology, sociology, with 3-hours at the 200+level), the natural sciences (9-hours - biology, chemistry, geology, microbiology, physical science, or physics (including both biological and physical, with six hours in the same science), literature (3-hours), history (3-hours), communications ( 3-hours - including speech communication, expository and technical writing courses, or THEA 261), the arts (3- hours) and other arts-humanities-behavioral sciences ( 3hours); a given curriculum may specify a particular course to fulfill a core requirement.

Civil engineering students must select their arts, humanities, and behavioral science courses from a list of department-approved electives. However, Industrial Economics and Finance, ECON 430, is required in satisfying 3-hours of the behavioral sciences requirement, and 3-hours of the humanities must include an ethics philosophy course. 
Learning Outcomes and Assessment: In the last ABET review (2007), the program outcomes were identified as being the criteria a-k of ABET Criterion 3 (Program Outcomes and Assessment) "with consideration and guidance provided by the American Society of Civil Engineers' Body of Knowledge (BOK1) for entry into the practice of civil engineering at the professional level”. In ASCE BOK1, 15 outcomes were identified and included a requisite learning or knowledge level for each using Bloom's cognitive domain. The first 11 ASCE BOK1 outcomes are essentially the same as the 11 outcomes (a-k) of ABET. The [University A's] program's objectives address the educational preparation for professional practice as a civil engineer and, as such, an obligation to seek compatibility with ASCE Policy Statement (PS) 465. At the time of the ABET visit, the University of Louisiana was in the process of identifying and making adjustments necessary for the program and the assessment system to fully comply with the three additional bachelor-level outcomes required for the future professional civil engineer in the BOK1. Although all of the BOK1 learning outcomes existed to some extent within the curriculum, the University of Louisiana program used only the required outcomes of ABET Criterion 3 (a-k) for assessment in the 2007 review.

In 2008, the 2008-09 ABET Criteria for Civil Engineering was used to justify an additional curriculum requirement for a 1-hour course. A senior seminar, CIVE 444, was approved by the University of Louisiana's Administration to assist in addressing the additional learning outcomes. This produces a program with 129 semester hours that became effective for students entering the program in the fall 2009. Further program improvements and assessment beyond that of the last ABET review have been established to further develop and evaluate the additional BOK1 outcomes, Table 2. Current efforts to solidify the most recent changes and investigate ways for achieving full BOK2 compliance are being reviewed.

\section{Evaluation of Current Curriculum vs. BOK2 Outcomes}

The University of Louisiana's current assessment of outcomes is compatible with BOK1 and ABET 2009-2010 Criteria. Table 3 is a comparison of the University of Louisiana's assessment of its current learning outcomes with the BOK2 outcomes. It is an adaptation of Table H-1 in the second edition of the Civil Engineering Body of Knowledge for the 21st Century (BOK2, 2008). As can be seen from the table, the BOK2 outcomes are a further refinement of the ABET/BOK1 outcomes that are expanded and with greater specification in their description. This refinement has produced the need for a redesigned curriculum with additional information and assessment measurements. BOK2 increases the number of individual outcomes and requires greater assessment detail. In addition to expanding the number of outcomes, the levels of achievement (LOA) for each must also be addressed.

In reviewing the University of Louisiana's civil engineering program with respect to the BOK2 outcomes, consideration was given to 1) whether the BOK2 outcome as stated was covered in the curriculum, 2) the extent of emphasis or LOA, and 3) whether the outcome as stated was being assessed. [University A] considers an outcome to exist only if it is identified as being integral and systematically included within the program; and then only if success is measured and documented. Without a BOK2 assessment system in place, an analysis was based on an estimate of the BOK2 outcomes status in the existing program and is believed to be on the conservative 
side. Figure 3 is a graphical presentation of the anticipated success for the current program of study in achieving the BOK2 outcomes and the corresponding LOA.

As seen in Figure 3, complete success in fulfilling the "challenging outcomes" is not being achieved in today's curriculum/program design. The columns and cells in Figure 3, correspond to the individual BOK2 outcomes and level of achievement. Complete success by the [University A's] curriculum is shown as green when the outcome LOA is accomplished by all graduates of the program and as yellow when the LOA is not fully achieved. The "challenging outcomes" include the nine "red outcomes" shown in Figures 2 and 3 (i.e., Outcomes 3 Humanities, 4 - Social Sciences, 10 - Sustainability, 11 - Contemporary Issues \& History, 12 Risk \& Uncertainty, 17 - Public Policy, 18 - Business \& Public Administration, 19 Globalization, and 20 - Leadership). In addition, the BOKEdFC committee identified Outcomes 5 - Material Science and Outcome 24 - Professional \& Ethics, shown in red, as outcomes that may be challenging for some programs to fully implement.

The University of Louisiana's participation in the BOKEdFC committee's BOK2 survey offered an opportunity for an internal review of the existing curriculum. A “devil's advocate" approach was employed in considering the curriculum's presentation of the learning outcomes and their assessment. So, in addition to the "challenging outcomes" identified in the study, other outcomes were also noted as needing further thought and, as shown in Figure 3, include the following:

BOK2 Outcome 7 - Experiments - The current BOK1 outcome wording raises more concern then the proposed BOK2 outcome statement. BOK1 requires the graduate to design a civil engineering experiment to meet a need; conduct, analyze and interpret. The extent and consistency to which all graduates have been challenged to design the required tests for a situation has been questioned. This is being addressed with modification of course outlines. The BOK2 outcome statement, "analyze the results of experiments and evaluate the results within known boundaries of the tests and materials in and across more than one technical area," is currently in place. Further development of the BOK1 outcome assessment demonstrating full compliance, i.e., "design a civil engineering experiment," is now in place, and BOK2 Outcome 7 is being achieved.

BOK2 Outcome 22 - Attitudes - BOK1 Outcome 15 combines professional attitudes with leadership. However, BOK2 stresses the importance of attitudes in the practice of professional engineering by identifying it as a specific outcome to be measured. The assessment of an individual's attitudes in a meaningful way is difficult ${ }^{6}$. The BOK2 Outcome 22 does not require that the attitudes of graduates be measured, but instead requires that they be able to "explain attitudes supportive of the professional practice in civil engineering." At [University A], these are being introduced in the CIVE 101, Introduction to Civil Engineering, and culminating through discussions in the recently added CIVE 444, Senior Seminar. 


\section{Current Curriculum and the “Challenging” BOK2 Outcomes}

All of the BOK2 outcomes noted as being "challenging” to many programs by the BOKEdFC 5 study were thought to be problematic to the University of Louisiana. It is anticipated that in order to fully address those BOK2 outcomes noted, the University of Louisiana will have to make some significant modifications.

The University of Louisiana's core curriculum requirements include 27-hours of humanities, arts, behavioral sciences, and communications. It is acceptable for a given curriculum to specify a particular course to fulfill a core requirement. The humanities \& social sciences outcomes (H\&SS) are generally thought of as being satisfied/addressed by the H\&SS electives required in the general education (core courses) component of the program. However, the BOK2 learning outcomes require the ability to demonstrate the importance of the humanities and social sciences, individually, to the practice of engineering. This is generally not the direction taken in most H\&SS electives. A review of available H\&SS courses have identified a small number that could contribute to this educational goal. However, it may require further demonstration and reinforcement in the technical courses. The importance of the humanities in the practice of civil engineering may be included as additional information in some of the design or planning courses. This outcome has not been established as a learning objective of any required design course, however. Methods to ensure integration of this issue into the design principles being covered would have to be developed.

BOK2 Outcome 5, Material Science, states that graduates should be able to use material science knowledge to solve problems appropriate to civil engineering, (Level 3). [University A] does not require a course devoted to material science. Material science principles are referred to in related but different materials-focused courses. The performance of graduating students on the portion of the FE exam has been erratic, and confidence that all graduates will consistently achieve the BOK2 LOA is not strong. Coverage of material science basics has not been established as being consistently included. However, other courses use and reference material science fundamentals in the presentation of their topics.

The importance of sustainability, contemporary issues and history, and risk and uncertainty concepts for the $21^{\text {st }}$ century professional civil engineer is identified by BOK2 Outcomes, 10, 11 and 12. Many, maybe most, programs are still experimenting with ways of presenting and integrating these principles within their academic curricula. The University of Louisiana's program has not, at this time, established how or where these concepts will be presented and assessed. Although these educational objectives are being addressed, the consistency or effectiveness of the academic experiences within the program has not been firmly established.

The five BOK2 Outcomes 17-Public Policy, 18-Business \& Public Administration, 19Globalization, 20- Leadership, and 22- Attitudes were formerly combined into three BOK1 outcomes. Separating the outcomes to ensure greater clarity requires greater detail in effort to adequately cover and assess the learning achieved. At the time of the BOKEdFC analysis, the University of Louisiana was focused on further development of the ABET/BOK1 requirements for accreditation. With increased emphasis or details and divisions that splinter the original ABET/BOK1 outcomes, the University of Louisiana rated its current program conservatively and with less confidence in its current ability to fully meeting BOK2's outcomes. 


\section{Curricular Changes Needed to Fully Implement the BOK2}

It is anticipated that in order to fully address the challenging BOK2 outcomes noted, the University of Louisiana will have to make some significant modifications. The options currently being considered include the following:

Outcome 3 - Humanities:

The humanities include literature, foreign language, history, communications, philosophy, and interdisciplinary studies. Currently, the humanities are satisfied in the civil engineering curriculum with an elective in history (3-hours), an arts elective (3- hours), a communications elective (3-hours), a literature elective (3-hours), and a philosophy-ethics elective (3-hours). Six-hours of English composition are also required.

Until BOK2, the core curriculum was thought of as satisfying ABET's criterion 5(c) for the general education component. However, BOK2 envisions graduates with a bachelor's degree in civil engineering as having the ability to "demonstrate the importance of the humanities in the professional practice of engineering." There is concern that the students' experiences within their humanity course electives, alone, will not ensure success of this outcome. These courses are not necessarily focused on engineering's role or the humanities-engineering relationships.

Possibilities for further development of this learning outcome include reconsidering the general education course electives and identify those which would contribute best to the objectives. This would lead to less flexibility in the selection of humanity electives, but could strengthen an appreciation for the importance of humanistic needs in the solution of engineering issues. Of major importance in this approach is that the courses are taught by instructors from the humanity departments. Problems associated with this effort would be the availability of courses with the desired focus and interest of the H\&SS faculty.

BOK2 Outcome 3 can also be addressed in the Civil Engineering Seminar, CIVE 444. CIVE 444 was specifically added to the curriculum to ensure success in those outcomes that address professional issues.

Outcome 4-Social Sciences: The BOK2 states that graduates can "demonstrate the incorporation of social sciences knowledge into the professional practice of engineering." As reviewed in Outcome 3, the University of Louisiana's core curriculum includes 9-hours of behavioral science electives; a history elective, an Industrial Economics and Finance course (CIVE 430), and a free elective from any of the behavioral science areas. The faculty is very confident that students completing the program will have significant appreciation for the importance of incorporating economic principles in design and planning. However, performance in other social science areas may vary for the same reasons given above under Outcome 3. The selection of history and social science elective courses, in general, are being reviewed with consideration for those which would provide a better appreciation for social science issues in engineering practice. Since all electives must have departmental approval, it will result in a smaller list of electives available to the student in satisfying this requirement.

Outcome 5 - Material Science: There are several material courses that include and refer to basic material science principles. These courses may provide an opportunity to integrate 
additional material basics that are not currently being emphasized enough, i.e., atomic and molecular structure, bond types, chemical and electrical properties, corrosion mechanisms, etc. These would obviously include the Mechanics of Materials (ENGR 203), Geotechnical Engineering (CIVE 328), Steel Design Lab (CIVE 426L), Concrete Design Lab (CIVE 427L), Highway Engineering (CIVE 450) materials testing laboratory, Construction Engineering (CIVE 480), and others. It is believed that the material science knowledge required to solve problems appropriate for civil engineering (Level 3) can be achieved in existing material courses.

Outcome 10 - Sustainability: While the importance of sustainability in design and construction is understood, the faculty still wrestles with questions of presentation and the measurement of the individual student's ability to apply these principles. The program and system for reviewing sustainable options in each area of civil engineering covered by the [University A] program must be developed and made integral with existing design courses.

Outcome 11 - Contemporary Issues \& History: The BOK2 expects students, “drawing upon a broad education, explain the impact of historical and contemporary issues on the identification, formulation, and solution of engineering problems and explain the impact of engineering solutions on the economy, environment, political landscape, and society.” A three hour history elective is required as part of University of Louisiana's general education component. This is currently an open elective that any history course will satisfy. If this program requirement is to address this outcome, history courses involving the impact of technology must be specified. LOA assessment and further development could be included in the CIVE 444, Senior Seminar, course.

Outcome 12 - Risk \& Uncertainty: The BOK2 envisions graduates with a bachelor's degree in civil engineering capable of "applying the principles of probability and statistics to solve problems containing uncertainties.” A statistics elective is required in the curriculum and is reinforced through applications in engineering courses and laboratories. Opportunities to cover the application of statistics and probability of uncertainties in analysis and design courses needs to be further developed as a course outcome.

Outcome 17 - Public Policy: BOK2 requires that civil engineering programs produce graduates with the ability to "discuss and explain key concepts and processes involved in public policy.” Opportunities for introducing topics contributing to this outcome are relevant to many courses beginning with the CIVE 101, Introduction to Civil Engineering, and including CIVE 322, Introduction to Environmental Engineering; CIVE 435, Transportation Planning; CIVE 480, Construction Engineering; CIVE 442, Senior Civil Engineering Design; CIVE 444, Civil Engineering Seminar; and others. Another possibility would be to use the current social science (or political science) elective that addresses policy and mandate that it be used to address this outcome. A review of the learning objectives for different courses is necessary to ensure that this outcome could be systematically covered and assessed.

Outcome 18 - Business \& Public Administration: BOK2 graduates with a CE degree are expected to "explain key concepts and processes used in business and public administration." The principles covered in ECON 430, Industrial Economics and Finance, may address some key concepts and processes used in business and public administration. However, this course alone does not seem to cover the objectives for this outcome. An additional effort will be necessary to cover these concepts. 
Outcome 19 - Globalization: This outcome calls for the graduate to be able to "organize, formulate, and solve engineering problems within a global context." It is currently intended that these concepts are initially introduced in CIVE 101, Introduction to Civil Engineering, and covered as a course objective in the CIVE 444, Civil Engineering Seminar. However, courses involving design and especially the CIVE 442, Senior Design Project, will probably offer the best opportunity for assessment of the student's ability to organize, formulate, and solve engineering within a global context.

Outcome 20 - Leadership: Expectations for this outcome is for civil engineering graduates to "apply leadership principles to direct the efforts of a small, homogenous group." The attributes of a good leader are introduced in CIVE 101, Introduction to Civil Engineering. The surveying laboratory, CIVE 225L, requires small survey crews with students rotating job responsibilities, including the role of survey party chief. Opportunities to apply leadership principles are also inherent in the CIVE 442, Senior Design Project, which requires team organization and the direction of personnel with subdivided tasks and responsibilities. There are also opportunities by structuring student participation in extra-curricular activities. Assessment of these and the method for measuring success of this outcome need to be further developed.

Outcome 24 - Professional \& Ethics: This BOK2 outcome expects graduates to be able to "analyze a situation involving multiple conflicting professional and ethical interests to determine an appropriate course of action.” The ASCE and NSPE Ethics Codes are introduced in CIVE 101, Introduction to Civil Engineering. Also, discussions in courses frequently address issues which tie the concern for public welfare and safety with the engineer's obligation to properly perform those activities being covered in the course. Although a number of courses frequently include professional-ethical questions, a greater effort is needed to completely meet the analysis LOA requiring that all graduates can determine an acceptable course of action for situations involving multiple professional and ethical conflicting interests to determine an appropriate course of action. Professional ethics is one of the principal learning objectives for the recently required CIVE 444 course, Civil Engineering Seminar, and offers an opportunity to validate the student's ability to analyze complex issues.

\section{The BOK2-Complient Curriculum}

The University of Louisiana faculty recognizes the importance of the BOK2 educational objectives for the $21^{\text {st }}$ Century Civil Engineer. In initial efforts to achieve BOK2 goals, [University A] will continue to formally identify its educational outcomes as being consistent with the current ABET/BOK1 criteria. However, it is the University of Louisiana's intention to internally use the BOK2 definitions for describing those current ABET outcomes, Table 3.

In the preceding sections, the issues and opportunities for including the additional BOK2 outcomes were considered. The proposed solution will be dependent on the available resources and program limitations of the department and institution. Ensuring complete coverage and systematic learning experiences for all students requires significant curriculum changes. This will include modifying existing courses and limiting the selection of electives to specific courses that address the desired outcome. Flexibility in the selection of the general degree course requirements will be greatly reduced. 
It is anticipated that a BOK2-complient curriculum would, in general, consist of the same sequence of courses, Table 1, but with the following changes that address those outcomes identified as most "challenging."

\section{Outcome 3 - Humanities:}

To further ensure that students will be able to "demonstrate the importance of the humanities in the professional practice of engineering," the current Arts Elective will be restricted to either the University of Louisiana's ARCH 221 or DSGN 121. Both are acceptable as fine art electives for the university's general degree or core course requirement. ARCH 121 involves a survey of epochs of architecture and urbanism from Gothics to present. DSGN 121 addresses the history and theory of design from industrial revolution to the present. The Civil Engineering Seminar, CIVE 444, was also specifically added to the curriculum to ensure success in those outcomes that address these issues. Thus, the combination of humanity elective, with further development and assessment in the CIVE 444 course, would be used to demonstrate the symbiotic relationships of engineering with humanity.

\section{Outcome 4 - Social Sciences:}

The University of Louisiana's core curriculum includes 9-hours of behavioral science electives. Currently, a required history elective, a specific economics course (ECON 430), and a behavioral science elective address this issue. ECON 430, Industrial Economics and Finance, involves economic and financial considerations in the design and selections of industrial projects including capital growth, net present value, and related analytical procedures, the effects of taxation, inflation and risk.

To further reinforce the student's ability to "demonstrate the incorporation of social sciences knowledge into the professional practice of engineering," further restrictions for the history elective may include limiting the choice to HIST 383 or HIST 384. HIST 383, Technology and History, covers the impact of technological developments on attitudes, behavior, religion, industrial and agriculture public policies, urban life and the environment. HIST 384, Science and Society, explores methods and values in the scientific endeavor and the impact of scientific developments on attitudes, behavior, religion, industry and agriculture, public policies, urban life, and the environment.

Also, in further efforts to address BOK2 Outcome 17, Public Policy, the behavioral science elective will be limited to courses that address public policy issues. The philosophy ethics requirement will be changed to an arts/humanities/behavioral science elective to provide a little flexibility. Engineering ethics will be addressed through the measures taken to achieve BOK2 Outcome 24. Social science considerations in the professional practice of civil engineering will also take place in the Senior Seminar course, CIVE 444.

\section{Outcome 5 - Material Science:}

The material science knowledge required to solve problems appropriate to civil engineering (Level 3) can and will be achieved in existing material courses.

Outcome 10 - Sustainability:

Sustainability concepts will be introduced to civil engineering students in the freshman orientation, CIVE 101. Sustainable issues are also central to the first environmental 
engineering course, CIVE 322. For understanding and applying sustainability principles within design and construction, corresponding courses, primarily, the senior capstone design course, Civil Engineering Design (CIVE 442) and Construction Engineering (CIVE 480) will be included as course learning objective. Sustainability will be included for consideration in the CIVE 442 design criteria, and the finished project will be critiqued with respect to success and/or lost opportunities. In CIVE 480, Construction Engineering, sustainability in terms of construction methods and materials will also be included and evaluated.

\section{Outcome 11 - Contemporary Issues \& History:}

As noted in Outcome BOK 4, to further reinforce the student's ability to "demonstrate the incorporation of social sciences knowledge into the professional practice of engineering," changes for the history elective will include limiting the choice to HIST 383 or HIST 384 to provide the basics in considering the impact of historical and contemporary issues on the identification, formulation, and solution of engineering problems, and to explain the impact of engineering solutions on the economy, environment, political landscape, and society. The history elective is part of the University of Louisiana's general education component.

\section{Outcome 12 - Risk \& Uncertainty:}

The BOK2 envisions graduates with a bachelor's degree in civil engineering to "apply the principles of probability and statistics to solve problems containing uncertainties." A statistics elective is required in the curriculum and is reinforced through applications in engineering courses and laboratories. The design courses, CIVE 426, 427, 422, 429, 438, 442, and 450 will identify risk and uncertainty issues in engineering design and methods to achieve this educational outcome. This will include all civil engineering areas covered by the program.

\section{Outcome 17 - Public Policy:}

BOK2 requires the ability to "discuss and explain key concepts and processes involved in public policy." In order to focus the student's attention on public policy, in general, the required behavioral science elective will be limited to three courses that address this topic and also meet the general degree requirements. This will include political science courses, POLS 350, 452, and 457. POL 350, Public Policy, covers a substantive examination of public policies in the United States. POL 452, Environmental Policy, includes U.S. environmental policy focusing on formulation, legitimizing, implementation, and evaluation. POL 457, Public Policy Analysis, reviews the formal and informal processes of the development, administration, and evaluation of U.S. public policies. Further reinforcement and application to the practice of civil engineering will occur in the CIVE 101, Introduction to Civil Engineering; CIVE 322, Introduction to Environmental Engineering; CIVE 435, Transportation Planning; CIVE 480, Construction Engineering; CIVE 442, Senior Civil Engineering Design; CIVE 444, Civil Engineering Seminar, and others. A public policy learning objectives for one or more of the CIVE courses will be established and assessed.

\section{Outcome 18 - Business \& Public Administration:}

BOK2 graduates with a CE degree are expected to "explain key concepts and processes used in business and public administration." The principles covered in the required ECON 430, Industrial Economics and Finance, directly address key concepts and processes used in business and public administration. Although business and public administration concepts 
and processes may currently be addressed in various degrees and in different courses, consideration is being given to replace a current CIVE elective with a business course. BSAT 455, Management in Technological Organizations, provides an introduction to management approaches necessary in organizations specializing in engineering and technological innovations. Project management, research and development, industrial marketing and purchasing, and the organizational roles of engineers, technicians, and managers are explored.

\section{Outcome 19 - Globalization:}

The need for engineering solutions that have been organized, formulated, and solved within a global context are initially introduced in CIVE 101, Introduction to Civil Engineering. It is further reinforced in other courses through applications of the subject matter and identified as a course objective in CIVE 444, Civil Engineering seminar. Courses involving design, and especially the CIVE 442, Senior Design Project, will probably offer the best opportunity for assessment of the student's ability to organize, formulate, and solve engineering within a global context.

Outcome 20 - Leadership:

Leadership principles will be introduced in CIVE 101, Introduction to Civil Engineering, and CIVE 444, Senior Seminar. The CIVE 442, Senior Design Project, requires teaming and the direction of personnel with subdivided tasks and individual responsibilities. The individual's leadership abilities will be evaluated in the review of the project performance in CIVE 442. Consideration is also being given for an extra-curricular requirement in the CIVE 444, Senior Seminar, for the student to demonstrate previous or current success in a leadership role as an ASCE officer, committee chair, or other extra-curricular group assignment conducted and documented during his or her tenure at the University of Louisiana.

Outcome 24 - Professional \& Ethics:

The ASCE and NSPE Ethics Codes are introduced in CIVE 101, Introduction to Civil Engineering. Professional ethics is one of the principal learning objectives for the recently required CIVE 444 course, Civil Engineering Seminar, and will be used to validate the student's ability to analyze complex issues.

An abbreviated summary of the proposed curriculum changes to bring [University A's] civil engineering program into complete compliance with the BOK2 learning outcomes is provided in Table 4. The recent addition of the Senior Seminar course, CIVE 444, contributes greatly in assisting in the coverage of the topics and assessment of the learning objectives. The syllabus of activities for the CIVE 444 course will include the "challenging" BOK2 outcomes and specifically address the level of achievement.

This proposal is also dependent upon the continued existence and availability of courses that address the general degree requirements and their compatibility with BOK2 outcomes.

\section{Conclusions}

BOK1 identified four additional educational outcomes and provided definition with a means for measuring success of those outcomes required in the body of knowledge for the professional civil engineer of the $21^{\text {st }}$ Century. BOK2, shortly thereafter, produced greater detail and 
specificity to those learning outcomes identified by ABET and BOK1. As a result, the number of outcomes was expanded to 24 , and the level of achievement was raised for some.

The University of Louisiana could offer a BOK2 compliant program by requiring specific courses of what were formerly electives and by modifying existing courses. The anticipated actions required and their ramifications would include:

- It will require general degree courses that specifically address BOK2 outcomes and will greatly decrease the electives that are currently meeting general degree requirements.

- It may involve substituting a business or administration course for a current, openelective in civil engineering subjects.

- It will require modifying some civil engineering courses and will impact the material currently being covered.

Limited to a 129 credit hour program, the program becomes very rigid in attempting to address five civil engineering areas, the twenty four BOK2 learning outcomes that address the basic, technical and professional civil engineering outcomes, and meet elevated levels of accomplishment. In some cases:

- Less flexibility in scheduling required general study electives could extend the program of study, depending upon the availability and frequency of course offering.

- It may be a little more difficult to provide a full schedule of degree-credit courses for students that are slower in completing their prerequisite math and science courses.

- It may create greater loss in transfer credit (general degree \& other courses) for students coming from other programs or other schools.

\section{Bibliography}

1. ASCE Body of Knowledge Committee of CAP^3. 2004. Civil Engineering Body of Knowledge for the $21^{\text {st }}$ Century: Preparing the Civil Engineer for the Future, Reston, VA, January. (http://www.asce.org/raisethebar).

2. ASCE Body of Knowledge II Committee of CAP^3. 2008. Civil Engineering Body of Knowledge for the $21^{\text {st }}$ Century: Preparing the Civil Engineer for the Future, Second Edition, Reston, VA, January.

(http://www.asce.org/raisethebar).

3. ASCE Levels of Achievement Subcommittee of CAP^3. 2005. Levels of Achievement Applicable to the Body of Knowledge Required for Entry Into the Practice of Civil Engineering at the Professional Level, Reston, VA, September. (http://www.asce.org/raisethebar)

4. Bloom. B. S., Englehart, M. D., Furst. E. J., Hill, W. H., and Krathwohl, D. 1956. Taxonomy of Educational Objectives, the Classification of Educational Goals, Handbook I: Cognitive Domain. David McKay, New York, NY.

5. Fridley, K.J., et al., 2009. Educating the Future Civil Engineering for the New Civil Engineering Body of Knowledge,” Proceeding of the 2009 ASEE Annual Conference, June 2009, Austin, TX.

6. Hoadley, Peter, “The ASCE BOK and Attitude Assessment,” ASEE Proceedings of the 2007 Annual Conference and Exposition, June 2007, Honolulu, Hawaii 


\begin{tabular}{|c|c|c|c|c|c|c|c|}
\hline OUTCOME \# & OUTCOME TITLE & 1 & 2 & 3 & 4 & 5 & 6 \\
\hline 1 & Mathematics & B & B & B & & & \\
\hline 2 & Natural Sciences & B & B & B & & & \\
\hline 3 & Humanities & B & B & B & & & \\
\hline 4 & Social Sciences & B & B & B & & & \\
\hline 5 & Material Science & B & B & B & & & \\
\hline 6 & Mechanics & B & B & B & B & & \\
\hline 7 & Experiments & B & B & B & B & $M / 30$ & \\
\hline 8 & Problem Recognition \& Solving & B & B & B & $M / 30$ & & \\
\hline 9 & Design & B & B & B & B & B & E \\
\hline 10 & Sustainability & B & B & B & $\mathbf{E}$ & & \\
\hline 11 & Contemporary Issues \& History & B & B & B & $\mathbf{E}$ & & \\
\hline 12 & Risk \& Uncertainty & B & B & B & $\mathbf{E}$ & & \\
\hline 13 & Project Management & B & B & B & $\mathbf{E}$ & & \\
\hline 14 & Breadth in CE & B & B & B & B & & \\
\hline 15 & Tech Specialization & B & $M / 30$ & $\mathrm{M} / 30$ & $\mathrm{M} / 30$ & $M / 30$ & E \\
\hline 16 & Communication & B & B & B & B & E & \\
\hline 17 & Public Policy & B & B & $\mathbf{E}$ & & & \\
\hline 18 & Business \& Public Admin & B & B & $\mathbf{E}$ & & & \\
\hline 19 & Globalization & B & B & B & $\mathbf{E}$ & & \\
\hline 20 & Leadership & B & B & B & $\mathbf{E}$ & & \\
\hline 21 & Teamwork & B & B & B & $\mathbf{E}$ & & \\
\hline 22 & Attitudes & B & B & $\mathbf{E}$ & & & \\
\hline 23 & Lifelong Learning & B & B & B & $\mathbf{E}$ & $\mathbf{E}$ & \\
\hline 24 & Professional \& Ethics & B & B & B & B & $\mathbf{E}$ & E \\
\hline
\end{tabular}

Figure 1: Graphical Representation of the BOK2 Outcome Rubric 


\begin{tabular}{|c|c|c|c|c|c|c|c|}
\hline \multirow[b]{2}{*}{ OUTCOME \# } & \multirow[b]{2}{*}{ OUTCOME TITLE } & \multicolumn{6}{|c|}{ BLOOM'S LEVEL OF ACHIEVEMENT (LOA) } \\
\hline & & 1 & 2 & 3 & 4 & 5 & 6 \\
\hline 1 & Mathematics & 10 & 10 & 9 & 2 & 0 & 0 \\
\hline 2 & Natural Sciences & 10 & 10 & 9 & 2 & 0 & 0 \\
\hline 3 & Humanities & 6 & 5 & 3 & 2 & 0 & 0 \\
\hline 4 & Social Sciences & 7 & 4 & 2 & 1 & 0 & 0 \\
\hline 5 & Material Science & 9 & 7 & 5 & 2 & 0 & 0 \\
\hline 6 & Mechanics & 10 & 9 & 9 & 7 & 0 & 0 \\
\hline 7 & Experiments & 9 & 9 & 9 & 8 & 2 & 0 \\
\hline 8 & Problem Recognition \& Solving & 10 & 9 & 9 & 2 & 1 & 0 \\
\hline 9 & Design & 9 & 10 & 9 & 8 & 7 & 0 \\
\hline 10 & Sustainability & 6 & 3 & 2 & 2 & 0 & 0 \\
\hline 11 & Contemporary Issues \& History & 7 & 3 & 2 & 1 & 0 & 0 \\
\hline 12 & Risk \& Uncertainty & 7 & 3 & 2 & 1 & 0 & 0 \\
\hline 13 & Project Management & 9 & 9 & 6 & 0 & 0 & 0 \\
\hline 14 & Breadth in CE & 10 & 10 & 9 & 9 & 0 & 0 \\
\hline 15 & Tech Specialization & 9 & 7 & 5 & 3 & 0 & 0 \\
\hline 16 & Communication & 10 & 10 & 8 & 8 & 2 & 0 \\
\hline 17 & Public Policy & 5 & 4 & 0 & 0 & 0 & 0 \\
\hline 18 & Business \& Public Admin & 7 & 4 & 0 & 0 & 0 & 0 \\
\hline 19 & Globalization & 5 & 3 & 1 & 0 & 0 & 0 \\
\hline 20 & Leadership & 9 & 7 & 4 & 0 & 0 & 0 \\
\hline 21 & Teamwork & 9 & 8 & 7 & 2 & 0 & 1 \\
\hline 22 & Attitudes & 7 & 7 & 0 & 0 & 0 & 0 \\
\hline 23 & Lifelong Learning & 10 & 10 & 9 & 0 & 0 & 0 \\
\hline 24 & Professional \& Ethics & 10 & 10 & 7 & 5 & 0 & 0 \\
\hline
\end{tabular}

Figure 2: Number of Programs (out of 10) Reporting All of the BOK2 Outcomes at Each LOA are Fulfilled by All of Their Baccalaureate Graduates. ${ }^{5}$ 


\begin{tabular}{|c|c|c|c|c|c|c|c|c|}
\hline \multirow{2}{*}{$\begin{array}{c}\text { BOK2 } \\
\text { Outcome }\end{array}$} & \multirow{2}{*}{$\begin{array}{c}\text { BOK2 } \\
\text { Outcome Name }\end{array}$} & \multirow{2}{*}{$\begin{array}{c}\text { BSCE } \\
\text { Outcome }\end{array}$} & \multicolumn{6}{|c|}{ BLOOM'S LEVEL OF ACHIEVEMENT (LOA) } \\
\hline & & & 1 & 2 & 3 & 4 & 5 & 6 \\
\hline 1 & Mathematics & 1 & B & B & $\mathrm{B}$ & & & \\
\hline 2 & Natural Sciences & 1 & B & $\mathrm{B}$ & $\mathrm{B}$ & & & \\
\hline 3 & Humanities & Program Criteria & B & $\mathrm{B}$ & $\mathrm{B}$ & & & \\
\hline 4 & Social Sciences & Program Criteria & B & $\mathrm{B}$ & $\mathrm{B}$ & & & \\
\hline 5 & Material Science & & B & $\mathrm{B}$ & $\mathrm{B}$ & & & \\
\hline 6 & Mechanics & 1 & $\mathrm{~B}$ & $\mathrm{~B}$ & $\mathrm{~B}$ & $\mathrm{~B}$ & & \\
\hline 7 & Experiments & 2 & $\mathrm{~B}$ & $\mathrm{~B}$ & $\mathrm{~B}$ & $\mathrm{~B}$ & $\mathrm{M} / 30$ & \\
\hline 8 & Problem Recognition \& Solving & 5 & B & $\mathrm{B}$ & $\mathrm{B}$ & $\mathrm{M} / 30$ & & \\
\hline 9 & Design & 3 & B & $\mathrm{B}$ & $\mathrm{B}$ & $\mathrm{B}$ & $\mathrm{B}$ & $\mathrm{E}$ \\
\hline 10 & Sustainability & & B & $\mathrm{B}$ & B & $\mathrm{E}$ & & \\
\hline 11 & Contemporary Issues \& History & 8,10 & B & $\mathrm{B}$ & $\mathrm{B}$ & $E$ & & \\
\hline 12 & Risk \& Uncertainty & & B & $\mathrm{B}$ & $\mathrm{B}$ & $E$ & & \\
\hline 13 & Project Management & 13 & B & $\mathrm{B}$ & $\mathrm{B}$ & $\mathrm{E}$ & & \\
\hline 14 & Breadth in CE & Program Criteria & $\mathrm{B}$ & $\mathrm{B}$ & $\mathrm{B}$ & $\mathrm{B}$ & & \\
\hline 15 & Tech Specialization & 12 & $\mathrm{~B}$ & $\mathrm{M} / 30$ & $\mathrm{M} / 30$ & $\mathrm{M} / 30$ & $\mathrm{M} / 30$ & $\mathrm{E}$ \\
\hline 16 & Communication & 7 & $\mathrm{~B}$ & $\mathrm{~B}$ & $\mathrm{~B}$ & $\mathrm{~B}$ & $\mathrm{E}$ & \\
\hline 17 & Public Policy & 14 & $\mathrm{~B}$ & $\mathrm{~B}$ & $E$ & & & \\
\hline 18 & Business \& Public Admin & 14 & B & $\mathrm{B}$ & $E$ & & & \\
\hline 19 & Globalization & 8 & B & $\mathrm{B}$ & $\mathrm{B}$ & $\mathrm{E}$ & & \\
\hline 20 & Leadership & 15 & $\mathrm{~B}$ & $\mathrm{~B}$ & $\mathrm{~B}$ & $\mathrm{E}$ & & \\
\hline 21 & Teamwork & 4 & B & $\mathrm{B}$ & $\mathrm{B}$ & $\mathrm{E}$ & & \\
\hline 22 & Attitudes & & B & $\mathrm{B}$ & $\mathrm{E}$ & & & \\
\hline 23 & Lifelong Learning & 9 & B & $\mathrm{B}$ & B & $\mathrm{E}$ & $\mathrm{E}$ & \\
\hline 24 & Professional \& Ethics & 6 & B & $\mathrm{B}$ & $\mathrm{B}$ & $\mathrm{B}$ & $\mathrm{E}$ & $\mathrm{E}$ \\
\hline
\end{tabular}

Figure 3: Graphical Comparison of the University of Louisiana’s BSCE Program Level of Achievement to BOK2 Outcomes. 


\section{TABLE 1 BASIC-LEVEL CURRICULUM \\ Civil Engineering Program (Fall 2009) \\ University of Louisiana \\ Lafayette, Louisiana}

\begin{tabular}{|c|c|c|c|c|c|}
\hline \multirow[b]{2}{*}{$\begin{array}{l}\text { Year; } \\
\text { Semester }\end{array}$} & \multirow[b]{2}{*}{$\begin{array}{c}\text { Course } \\
\text { (Department, Number, Title) }\end{array}$} & \multicolumn{4}{|c|}{ Category (Credit Hours) } \\
\hline & & $\begin{array}{c}\text { Math \& } \\
\text { Basic } \\
\text { Sciences }\end{array}$ & $\begin{array}{c}\text { Engineering } \\
\text { Topics - } \\
\text { Check if } \\
\text { Contains } \\
\text { Significant } \\
\text { Design }(\checkmark) \\
\end{array}$ & $\begin{array}{c}\text { General } \\
\text { Education }\end{array}$ & Other \\
\hline \multirow{6}{*}{$\begin{array}{l}\text { First year; } \\
\text { Fall } \\
\text { semester } \\
16 \text { hrs }\end{array}$} & CHEM 107 General Chemistry I & 3 & & & \\
\hline & CIVE 101 Intro. to Civil Engineering & & 1 & & \\
\hline & CIVE 142 Civil Eng Graphics & & 2 & & \\
\hline & ENGL 101 Rhet and Comp & & & 3 & \\
\hline & MATH 270 Calculus I & 4 & & & \\
\hline & HIST Elective & & & 3 & \\
\hline \multirow{5}{*}{$\begin{array}{l}\text { First year; } \\
\text { Spring } \\
\text { semester } \\
16 \text { hrs }\end{array}$} & CHEM 108 General Chemistry II & 3 & & & \\
\hline & CHEM 115 General Chemistry Lab & 2 & & & \\
\hline & ENGL 102 Comp and Lit & & & 3 & \\
\hline & MATH 301 Calculus II & 4 & & & \\
\hline & PHYS 201 General Physics I & 4 & & & \\
\hline \multirow{5}{*}{$\begin{array}{l}\text { Second } \\
\text { year; } \\
\text { Fall } \\
\text { semester } \\
16 \text { hrs }\end{array}$} & CIVE 225 Surveying & & 3 & & \\
\hline & ENGR 211 Statics & & 3 & & \\
\hline & MATH 302 Calculus II & 4 & & & \\
\hline & BIO SCI Elective & 3 & & & \\
\hline & ARTS Elective & & & 3 & \\
\hline \multirow{5}{*}{$\begin{array}{l}\text { Second } \\
\text { year; } \\
\text { Spring } \\
\text { semester } \\
15 \text { hrs }\end{array}$} & ENGR 201 Electric Circuits & & 3 & & \\
\hline & ENGR 203 Mechanics of Materials & & 3 & & \\
\hline & MATH 350 Diff Equations & 3 & & & \\
\hline & BHSC Elective & & & 3 & \\
\hline & CMCN Elective & & & 3 & \\
\hline \multirow{5}{*}{$\begin{array}{l}\text { Third year; } \\
\text { Fall } \\
\text { semester } \\
15 \text { hrs }\end{array}$} & CIVE 328 Geotech Engineering & & 3 & & \\
\hline & CIVE 332 Structural Mech I & & 3 & & \\
\hline & ENGR 304 Fluid Mechanics & & 3 & & \\
\hline & ENGR 301 Thermodynamics & & 3 & & \\
\hline & ENGR 313 Dynamics & & 3 & & \\
\hline
\end{tabular}

(CONTINUED ON NEXT PAGE) 


\section{TABLE 1 BASIC-LEVEL CURRICULUM (CONTINUED) \\ Current Civil Engineering Program (Fall 2009) \\ University of Louisiana \\ Lafayette, Louisiana}

\begin{tabular}{|c|c|c|c|c|c|}
\hline \multirow[b]{2}{*}{$\begin{array}{c}\text { Year; } \\
\text { Semester }\end{array}$} & \multirow[b]{2}{*}{$\begin{array}{c}\text { Course } \\
\text { (Department, Number, Title) }\end{array}$} & \multicolumn{4}{|c|}{ Category (Credit Hours) } \\
\hline & & $\begin{array}{c}\text { Math \& } \\
\text { Basic } \\
\text { Sciences }\end{array}$ & $\begin{array}{c}\text { Engineering } \\
\text { Topics - } \\
\text { Check if } \\
\text { Contains } \\
\text { Significant } \\
\text { Design }(\checkmark) \\
\end{array}$ & $\begin{array}{l}\text { General } \\
\text { Education }\end{array}$ & Other \\
\hline \multirow{6}{*}{$\begin{array}{l}\text { Third year; } \\
\text { Spring } \\
\text { semester } \\
18 \text { hrs }\end{array}$} & CIVE 322 Environmental Engineering I & & 3 & & \\
\hline & CIVE 429 Hydrology & & 3 & & \\
\hline & $\begin{array}{l}\text { ECON } 430 \text { Industrial Economics and } \\
\text { Finance }\end{array}$ & & & 3 & \\
\hline & Literature Elective & & & 3 & \\
\hline & PHIL Ethics Elective & & & 3 & \\
\hline & STAT Elective & 3 & & & \\
\hline \multirow{5}{*}{$\begin{array}{l}\text { Fourth } \\
\text { year; } \\
\text { Fall } \\
\text { semester } \\
15 \text { hrs }\end{array}$} & CIVE 422 Environmental Engineering II & & $3(\checkmark)$ & & \\
\hline & CIVE 427 Reinforced Concrete Design & & $3(\checkmark)$ & & \\
\hline & CIVE 434 Hydraulics & & $3(\checkmark)$ & & \\
\hline & CIVE 450 Highway Engineering & & $3(\checkmark)$ & & \\
\hline & CIVE 480 Construction Engineering & & $3(\checkmark)$ & & \\
\hline \multirow{7}{*}{$\begin{array}{l}\text { Fourth } \\
\text { year; } \\
\text { Spring } \\
\text { semester } \\
17 \text { hrs }\end{array}$} & CIVE 426 Structural Design in Metals & & $2(\checkmark)$ & & \\
\hline & CIVE 435 Transportation Engineering & & $3(\checkmark)$ & & \\
\hline & CIVE 438 Foundation Engineering & & $3(\checkmark)$ & & \\
\hline & $\begin{array}{l}\text { CIVE } 442 \text { Civil Engineering Senior } \\
\text { Design }\end{array}$ & & $3(\checkmark)$ & & \\
\hline & CIVE 444 Senior Seminar & & 1 & & \\
\hline & CIVE Elective & & 3 & & \\
\hline & CIVE Elective & & 3 & & \\
\hline \multicolumn{2}{|c|}{ TOTAL-ABET BASIC-LEVEL REQUIREMENTS } & 33 & 69 & 27 & \\
\hline \multicolumn{2}{|c|}{ OVERALL TOTAL FOR DEGREE } & \multicolumn{4}{|c|}{129} \\
\hline \multicolumn{2}{|c|}{ PERCENT OF TOTAL } & $26 \%$ & $53 \%$ & $21 \%$ & \\
\hline \multirow{2}{*}{$\begin{array}{c}\text { Total } \\
\text { must satisfy } \\
\text { one set }\end{array}$} & Minimum semester credit hours & 32 & 48 & & \\
\hline & Minimum percentage & $25 \%$ & $37.5 \%$ & & \\
\hline
\end{tabular}




\section{TABLE 2 FALL 2009 PROGRAM OUTCOMES University of Louisiana}

\begin{tabular}{|c|c|c|}
\hline \multicolumn{3}{|c|}{ ВET/BOK1 } \\
\hline a / 1 & Technical core & $\begin{array}{l}\text { Can solve problems in mathematics through differential equations, } \\
\text { calculus-based physics, chemistry, and biology. (Level 3) }\end{array}$ \\
\hline b / 2 & Experiment & $\begin{array}{l}\text { Can design a civil engineering experiment to meet a need; conduct } \\
\text { the experiment, and analyze and interpret the resulting data. (Level } \\
\text { 5) }\end{array}$ \\
\hline c / 3 & Design & $\begin{array}{l}\text { Can design a complex system or process to meet desired needs, } \\
\text { within realistic constraints such as economic, environmental, } \\
\text { social, political, ethical and safety, constructability, and } \\
\text { sustainability. (Level 5) }\end{array}$ \\
\hline d / 4 & $\begin{array}{l}\text { Multi- } \\
\text { disciplinary }\end{array}$ & $\begin{array}{l}\text { Can function effectively as a member of a multi-disciplinary team. } \\
\text { (Level 3) }\end{array}$ \\
\hline e / 5 & $\begin{array}{l}\text { Engineering } \\
\text { problems }\end{array}$ & $\begin{array}{l}\text { Can solve well-defined engineering problems in structures, } \\
\text { geotechnical, transportation, water resources, and environmental } \\
\text { engineering. (Level 3) }\end{array}$ \\
\hline$f / 6$ & $\begin{array}{l}\text { Professional } \\
\text { /ethical }\end{array}$ & $\begin{array}{l}\text { Can analyze situations involving conflicting professional and } \\
\text { ethical interests, to determine an appropriate course of action. } \\
\text { (Level 4) }\end{array}$ \\
\hline g/ 7 & Communication & $\begin{array}{l}\text { Can organize and deliver effective verbal, written, and graphical } \\
\text { communications. (Level 4) }\end{array}$ \\
\hline h / 8 & $\begin{array}{l}\text { Engineering } \\
\text { impact }\end{array}$ & $\begin{array}{l}\text { Can determine impact of a specific, relatively constrained } \\
\text { engineering (Level 3) }\end{array}$ \\
\hline i / 9 & $\begin{array}{l}\text { Life-long } \\
\text { learning }\end{array}$ & $\begin{array}{l}\text { Can demonstrate the ability to learn on their own, without the aid } \\
\text { of formal instruction. (Level 3) }\end{array}$ \\
\hline $\mathrm{j} / \mathbf{1 0}$ & $\begin{array}{l}\text { Contemporary } \\
\text { issues }\end{array}$ & $\begin{array}{l}\text { Can incorporate specific contemporary issues into the } \\
\text { identification, formulation, and solution of a specific engineering } \\
\text { problem. (Level 3) }\end{array}$ \\
\hline k / 11 & $\begin{array}{l}\text { Engineering } \\
\text { tools }\end{array}$ & $\begin{array}{l}\text { Can apply relevant techniques, skills, and modern engineering } \\
\text { tools to solve a simple problem. (Level 3) }\end{array}$ \\
\hline $\begin{array}{l}\text { Civil } \\
\text { Programs } \\
/ 13 \\
\end{array}$ & $\begin{array}{l}\text { Project, asset, } \\
\text { construction } \\
\text { management }\end{array}$ & $\begin{array}{l}\text { Can explain key concepts and problem-solving processes used in } \\
\text { management (Level 2) }\end{array}$ \\
\hline $\begin{array}{c}\text { Civil } \\
\text { Programs } \\
/ 14 \\
\end{array}$ & $\begin{array}{l}\text { Business, public } \\
\text { policy, \& public } \\
\text { administration }\end{array}$ & $\begin{array}{l}\text { Can explain key concepts and problem-solving processes used in } \\
\text { business, public (Level 2) }\end{array}$ \\
\hline $\begin{array}{l}\text { Civil } \\
\text { Programs } \\
\quad / 15\end{array}$ & Leadership & $\begin{array}{l}\text { Can explain the role of the leader, leadership principles, and } \\
\text { attitudes conducive to effective professional practice of civil } \\
\text { engineering. (Level 2) }\end{array}$ \\
\hline
\end{tabular}




\section{TABLE 3 ABET Program criteria vs BOK2 Outcomes}

\begin{tabular}{|c|c|}
\hline $\begin{array}{l}\text { ABET \& Program Criteria } \\
\text { for Civil and Similarly } \\
\text { Named Engineering } \\
\text { Programs (BOK1 Outcomes) }\end{array}$ & BOK2 Outcomes \\
\hline 1. Technical core (Level 3) & $\begin{array}{l}\text { 1. Mathematics (Level 3) } \\
\text { 2. Natural Sciences (Level 3) } \\
\text { 5. Materials science (Level 3) } \\
\text { 6. Mechanics (Level 4) }\end{array}$ \\
\hline 2. Experiments (Level 5) & 7. Experiments (Level 4) \\
\hline 3. Design (Level 5) & $\begin{array}{l}\text { 9. Design (Level 5) } \\
\text { 10. Sustainability (Level 3) } \\
\text { 12. Risk/uncertainty (Level 3) }\end{array}$ \\
\hline $\begin{array}{l}\text { 4. Multidisciplinary teams } \\
\text { (Level 3) }\end{array}$ & 21. Teamwork (Level 3) \\
\hline $\begin{array}{l}\text { 5. Engineering Problems } \\
\text { (Level 3) }\end{array}$ & $\begin{array}{l}\text { 8. Problem recognition and solving (Level 3) } \\
14 \text { Breadth in civil engineering areas (Level 4) }\end{array}$ \\
\hline $\begin{array}{l}\text { 6. Professional and ethical } \\
\text { responsibility (Level 2) }\end{array}$ & 24. Professional and ethical responsibility (Level 4) \\
\hline 7. Communication (Level 4) & 16. Communication (Level 4) \\
\hline $\begin{array}{l}\text { 8. Impact of engineering } \\
\text { (Level 2) }\end{array}$ & 11. Contemporary issues and historical perspectives (Level 3) \\
\hline 9. Lifelong learning (Level 3) & 23. Lifelong learning (Level 3) \\
\hline $\begin{array}{l}\text { 10. Contemporary issues } \\
\text { (Level 2) }\end{array}$ & $\begin{array}{l}\text { 11. Contemporary issues and historical perspectives (Level 3) } \\
\text { 19. Globalization (Level 3) }\end{array}$ \\
\hline $\begin{array}{l}\text { 11. Engineering tools (Level } \\
\text { 3) }\end{array}$ & 8. Problem recognition and solving (Level 3) \\
\hline $\begin{array}{l}\text { 12. Specialization area related } \\
\text { to civil engineering* }\end{array}$ & 15. Technical specialization (Level 1) \\
\hline $\begin{array}{l}\text { 13. Project management, } \\
\text { construction, and asset } \\
\text { management (Level 2) }\end{array}$ & 13. Project management (Level 3) \\
\hline $\begin{array}{l}\text { 14. Business and public policy } \\
\text { (Level 2) }\end{array}$ & $\begin{array}{l}\text { 17. Public policy (Level 2) } \\
\text { 18. Business and public administration (Level 2) }\end{array}$ \\
\hline 15. Leadership (Level 2) & $\begin{array}{l}\text { 20. Leadership (Level 3) } \\
\text { 22. Attitudes (Level 2) }\end{array}$ \\
\hline EAC/ABET Criterion 5 & $\begin{array}{l}\text { 3. Humanities (Level 3) } \\
\text { 4. Social sciences (Level 3) }\end{array}$ \\
\hline $\begin{array}{l}\text { Program Criteria for Civil and } \\
\text { Similarly Named Engineering } \\
\text { Programs }\end{array}$ & 14. Breadth in civil engineering areas (Level 4) \\
\hline
\end{tabular}




\section{Table 4 Summary of Proposed Curriculum Changes to address the BOK2 Challenging Outcomes - University of Louisiana}

\begin{tabular}{|c|c|c|}
\hline BOK2 Outcome & $\begin{array}{l}\text { Program Location } \\
\text { Topic Coverage }\end{array}$ & Assessment \\
\hline 3 - Humanities & $\begin{array}{l}\text { General degree requirement } \\
\& \text { CIVE } 444\end{array}$ & CIVE 444 - CE Seminar \\
\hline 4 - Social science & $\begin{array}{l}\text { General degree requirement } \\
\text { \& CIVE } 444\end{array}$ & CIVE 444 - CE Seminar \\
\hline 5 - Material science & Existing material courses* & Material courses \\
\hline 10 - Sustainability & Design courses* & CIVE 442 - Senior Design \\
\hline $\begin{array}{l}\text { 11- Contemporary issues } \\
\text { \& history }\end{array}$ & $\begin{array}{l}\text { General degree requirement } \\
\text { \& CIVE } 444\end{array}$ & CIVE 444 - CE Seminar \\
\hline 12 - Risk \& uncertainty & Existing design courses* & CIVE design courses \\
\hline 17 - Public policy & $\begin{array}{l}\text { General degree requirement } \\
\text { \& CIVE } 444\end{array}$ & CIVE 444 - Senior Design \\
\hline $\begin{array}{c}18 \text { - Business \& public } \\
\text { administration }\end{array}$ & $\begin{array}{l}\text { Business administration } \\
\text { course (former CIVE Elect) }\end{array}$ & CIVE 444 - Senior Design \\
\hline 19 - Globalization & CIVE 442 & CIVE 442 - Senior Design \\
\hline 20 - Leadership & CIVE 101 \& 444 & CIVE 444 - Senior Seminar \\
\hline $\begin{array}{l}24 \text { - Professional \& ethical } \\
\text { responsibility }\end{array}$ & CIVE $101 \& 444$ & CIVE 444 - Senior Seminar \\
\hline
\end{tabular}

